\title{
Effects of the Global and Domestic Business and Economic Factors on Aggregate Output in Austria
}

\author{
Yu Hsing ${ }^{1} \&$ Mario Krenn ${ }^{1}$ \\ ${ }^{1}$ College of Business, Southeastern Louisiana University, USA \\ Correspondence: Yu Hsing, College of Business, Southeastern Louisiana University, LA 70402, USA. Tel: \\ 1-985-549-2086. E-mail: yhsing@selu.edu
}

Received: January 26, 2016

Accepted: January 29, $2016 \quad$ Online Published: February 26, 2016

doi: 10.20849/abr.v1i1.7

URL: http://dx.doi.org/10.20849/abr.v1i1.7

\begin{abstract}
Based on a quarterly sample during 2003.Q1-2015.Q1, this paper finds that Austria's aggregate output is positively affected by the lagged German or U.S. output, the real oil price and labor productivity and is negatively influenced by real effective exchange rate appreciation, the real lending rate, central government debt as a percent of GDP and the expected inflation rate. Hence, a rising oil price would not harm aggregate output, and recent depreciation of the euro would be beneficial to aggregate output.
\end{abstract}

Keywords: exchange rates, government debt, productivity, foreign income, oil prices

\section{Introduction}

There are strengths and weaknesses in Austria's economy. The inflation rate of $1.5 \%$ in 2014 was below the 2\% inflation target. The respective interest rates of $2.29 \%$ and $4.93 \%$ in 2014 for household consumption and house purchase were considered reasonable and affordable. The 5.6\% unemployment rate in 2014 suggests that the labor market condition was much better than most of the other EU countries. The $2.75 \%$ central government budget deficit as a percent of GDP in 2014 met the criterion of the Maastricht treaty. However, the annual economic growth rate of $0.4 \%$ in 2014 was below the average long-term growth rate. The $84.2 \%$ general government public debt as a percent of GDP in 2014 was higher than the $60 \%$ criterion of the Maastricht treaty. Trade deficit has improved as it changed from -8.439 billion euro in 2012 to 1.741 billion euro in 2014. The stock market has not recovered from the global financial crisis as the ATX index declined $50.7 \%$ from a high of 4859.72 in June 2007 to 2396.02 in December 2015 (The Oesterreichische Nationalbank, 2016).

Recently several external and internal developments may affect business and economic activities in Austria. The exchange rate measured as units of the US. Dollar per euro declined 30.91\% from a high of 1.5768 in July 2008 to a low of 1.0894 on January 18, 2016. Although exchange rate depreciation would help the exporting sector, the domestic economy may face potential issues such as higher import prices and inflation. World oil prices have been on the decline since June 2014. Whether declining oil prices would be beneficial to the Austrian economy remains to be seen. On the one hand, cheaper gasoline prices may cause consumers to spend more on other items, and cheaper energy costs would reduce production costs, lower the price level, and raise aggregate output. On the other hand, Austria has a diversified energy generation portfolio, it is increasingly energy self-sufficient, and aggressively promotes the production of energy from renewable resources (World Energy Council, 2015). Therefore, the country may not be affected significantly by oil price changes. Internally, the government's priorities in public finance policies have likely been shifted by recent political changes. At the beginning of January 2007, Austria government changed from a coalition government between the center-right Austrian People's Party and the conservative-right Freedom Party of Austria to a grand coalition government formed by the center-left Social Democratic Party of Austria and the center-right Austrian People's Party. The grand coalition government was reelected in 2008 and 2013 (Bundeskanzleramt Oesterreich, 2016). This paper attempts to examine the impacts of several global and domestic business and economic factors on Austria's aggregate output. In addition to the above-mentioned global factors, the real interest rate, labor productivity, fiscal policy, etc. will be considered.

\section{Model}

Based on aggregate demand and aggregate supply analysis, the reduced form of the equilibrium aggregate output 
is given by:

$$
\begin{gathered}
Y=f\left(E X, W Y, O P, I R, P D, D Y, \pi^{e}\right) \\
?+? \quad+\quad+\quad-
\end{gathered}
$$

$\mathrm{Y}=$ equilibrium aggregate output in Austria,

$\mathrm{EX}=$ the real effective exchange rate (An increase means appreciation of the euro.),

$\mathrm{WY}=$ foreign income

$\mathrm{OP}=$ real oil price

$\mathrm{IR}=$ the real interest rate

$\mathrm{PD}=$ labor productivity

$\mathrm{DY}=$ central government debt as a percent of aggregate output

$\pi^{e}=$ the expected inflation rate

We expect that aggregate output has a positive relationship with foreign income, labor productivity, a negative relationship with the real interest rate and the expected inflation rate, and an unclear relationship with the real exchange rate, the real oil price, and government debt as a percent of aggregate output.

A higher world income is likely to benefit Austria's economy due to more exports to other countries. A higher labor productivity increases short-run aggregate supply at the given level of the inflation rate. A higher real interest rate expects to reduce borrowing by consumers and businesses and private spending. A higher expected inflation rate reduces short-run aggregate supply at the given level of the inflation rate.

Exchange rate depreciation tends to increase exports and shift aggregate demand to the right and tends to increase import costs and shift aggregate supply to the left. Hence, its net impact on aggregate output may be positive, negative or neutral. Gylfason and Risager (1984) show that devaluation is contractionary in six of eight developing countries and expansionary in four of seven developed countries. Kalyoncu, Artan, Tezekici, and Ozturk (2008) study the impact of real exchange rate depreciation on output for 23 OECD countries including Austria. The results vary with countries and differ in the short and long run. In the short run, exchange rate depreciation has a positive effect on output for Hungary and Switzerland and a negative impact on output for Finland, Germany and Turkey, and a neutral effect for the other 18 remaining countries. In the long run, exchange rate depreciation has a positive impact on output for Finland, Germany and Sweden and a negative impact on output for Austria, Hungary, Poland, Portugal, Switzerland and Turkey. Kim (2015) find that devaluation is more likely to be expansionary in six selected developed countries whereas devaluation tends to be contractionary in seven selected developing countries.

High volatility of oil prices creates uncertainty, which tends to increase saving and reduce investment spending (Guo \& Kliesen, 2005). High oil prices have indirect effects of changing consumption patterns, disturbing resource allocations, and increasing unemployment (Hamilton, 2005). Supply-driven oil price increases in the 1970s led to recessions whereas demand-driven oil price increases in recent years may affect economic activities differently in the short run and long run (Hamilton, 1996; Segal, 2011). Kilian (2008b) shows that a higher oil price due to aggregate demand shocks results in a positive effect on real GDP initially and a negative effect on real GDP in the long run. However, Austria's increasing energy self-sufficiency may shield the country's economy from the effects commonly associated with oil price fluctuations (World Economic Council, 2015).

Recent political changes in Austria may have shifted government spending policies. An increase in government debt as a percent of aggregate output may or may not affect aggregate output. If the debt is below certain threshold level and used to improve infrastructures, the impact of the debt may be positive. The Ricardian equivalence hypothesis (Barro, 1974, 1989) suggests that debt-financed government spending has a neutral effect on aggregate output whereas Feldstein (1976) and Buchanan (1976) hold a different view. Cebula (1997), Cebula and Cuellar (2010), Cebula (2014a, 2014b), and Cebula, Angjellari-Dajci, and Foley (2014) indicate that deficit-financed government spending raises the real interest rate and may reduce spending in the private sector.

\section{Results}

The data were collected from the International Financial Statistics published by the IMF. Aggregate output is represented by real gross domestic product (GDP) measured in billions of the euro. The real effective exchange rate is a trade-weighted exchange rate, and an increase means real appreciation of the euro. Hence, an increase in the real exchange rate means real depreciation of the euro. Foreign income is represented by the lagged real GDP in Germany as Austria's economy is likely to respond to Germany's economy with a lag. The real GDP of 
Germany may have a more direct effect on Austria aggregate output. Germany is Austria main trading partner. $30 \%$ of Austria exports go to Germany vs. $6 \%$ to the USA; $40 \%$ of Austria's imports come from Germany vs. $4 \%$ from the USA (Kompetenzzentrum Forschungsschwerpunkt Internationale Wirtschaft, 2016). The real oil price is derived from the average world oil price per barrel measured in the euro and adjusted for the consumer price index in Austria. The real interest rate is equal to the nominal lending rate for 5-year to 10-year loans minus the expected inflation rate where the expected inflation rate is the average inflation rate of the past four quarters. The inflation rate is measured by the percent change in the consumer price index. Labor productivity is represented by real GDP per employee and measured in thousands of the euro. Central government debt is measured as a percent of nominal GDP. Except for the real lending rate and the expected inflation with negative values before or after transformation to the log scale, other variables are measured in the log scale in order to reduce the multicollinearity problem. The sample ranges from 2003.Q1 to 2015.Q1 and has 49 observations. Earlier data for the lending rate are not available before 2003.Q1.

The estimated regression and related statistics are reported in Table 1. Approximately $95.35 \%$ of the variation in aggregate output can be explained by the seven explanatory variables. All the estimated coefficients are significant at the $1 \%$ or $5 \%$ level. Aggregate output is negatively associated with the real effective exchange rate, the real lending rate, central government debt as a percent of GDP and the expected inflation rate and is positively affected by the lagged German output, the real oil price and labor productivity.

The negative significant coefficient of the real effective exchange rate suggests that the negative impacts of real appreciation are greater than the positive impacts of real appreciation. If the lagged German real GDP rises $1 \%$, Austria's real GDP would increase $0.2436 \%$.

Table 1. Estimated regression of aggregate output in Austria

\begin{tabular}{lcc}
\hline Dependent variable: Log(aggregate output) & Coefficient & z-Statistic \\
\hline Intercept & 2.1713 & 39.7269 \\
Log(real effective exchange rate) & -0.4435 & -11.1569 \\
Log(lagged German real output) & 0.2436 & 5.2677 \\
Log(real oil price) & 0.0353 & 7.2109 \\
Real lending rate & -0.0116 & -6.2493 \\
Log(productivity) & 0.9007 & 14.5099 \\
Log(debt/GDP ratio) & -0.0640 & -2.0960 \\
Expected inflation rate & -0.0155 & -6.4187 \\
R-squared & 0.9535 & \\
Adjusted R-squared & 0.9413 & \\
F-statistic & 77.9578 & \\
MAPE & $1.0194 \%$ & \\
Methodology & EGARCH & \\
Sample period & $2003 . Q 1-2015 . Q 1$ & \\
Sample size & 49 & \\
\hline
\end{tabular}

All the coefficients are significant at the 1\% level. EGARCH is the exponential GARCH model.

A higher real oil price would raise aggregate output. A higher real lending rate would reduce aggregate output because of a higher cost of borrowing for consumers and businesses. A $1 \%$ increase in labor productivity is expected to raise aggregate output by $0.9007 \%$. A $1 \%$ increase in the debt/GDP ratio would reduce aggregate output by $0.0640 \%$, suggesting that fiscal policy may need to be more prudent.

Several other versions have been considered. When the lagged U.S. output replaces the lagged German output, the coefficient is estimated to be 0.1826 and is significant at the $5 \%$ level. Other results are similar. When both the lagged U.S. and German real GDP are included in the regression, the positive coefficient of the lagged U.S. real GDP is significant at the $1 \%$ level whereas the positive coefficient of the lagged German real GDP is 
insignificant at the $10 \%$ level due to a high degree of multicollinearity.

\section{Discussion}

We have examined the impacts of the global and domestic business and economic factors on aggregate output in Austria. Depreciation of the real effective exchange rate, more U.S. or German output, a higher real oil price, a lower real lending rate, a higher labor productivity, a lower government debt/GDP ratio or a lower expected inflation rate would increase aggregate output. The relatively high value of R-squared and low forecast error suggest that the model can capture most of the change in aggregate output.

Some global factors such as the euro exchange rate, the world oil price and the U.S. or German output are beyond Austria's control. However, the Austrian government may need to take measures to increase labor productivity such as enhancing IT related education and promotion of IT usage in enterprises, reducing the regulatory burden for small businesses, and supporting alternative means of financing for entrepreneurs (e.g. venture capital). The government may also need to exercise fiscal prudence, lower the real interest rate to encourage households and businesses to increase spending, and reduce inflation expectations. Additionally, Austria's government may also need to more aggressively generate domestic support for the Transatlantic Trade and Investment Partnership (T-TIP) as a means to diversify the country's trade and investment beyond the European Union and to reduce its economic and political dependence on Germany.

\section{References}

Barro, R. J. (1974). Are government bonds net wealth? Journal of Political Economy, 82(6), 1095-1117. http://dx.doi.org/10.1086/260266

Barro, R. J. (1989). The Ricardian approach to budget deficits. Journal of Economic Perspectives, 3(2), 37-54.

Buchanan, J. M. (1976). Barro on the Ricardian equivalence theorem. Journal of Political Economy, 84(2), 337-342. Retrieved from http://www.jstor.org/stable/1831905

Bundeskanzleramt Oesterreich. (2016). Kanzler und Regierungen seit 1945. Retrieved from https://www.bka.gv.at/site/3355/default.aspx

Cebula, R. J. (1997). An empirical note on the impact of the federal budget deficit on ex ante real long term interest rates, 1973-1995. Southern Economic Journal, 63(4), 1094-1099. Retrieved from http://www.jstor.org/stable/1061244

Cebula, R. J. (2014a). Impact of federal government budget deficits on the longer-term real interest rate in the US: evidence using annual and quarterly data, 1960-2013. Retrieved from https://mpra.ub.uni-muenchen.de/id/eprint/55264

Cebula, R. J. (2014b). An empirical investigation into the impact of US federal government budget deficits on the real interest rate yield on intermediate-term treasury issues. 1972-2012. Applied Economics, 46(28), 3483-3493. http://dx.doi.org/10.1080/00036846.2014.932050

Cebula, R. J., \& Cuellar, P. (2010). Recent evidence on the impact of government budget deficits on the ex ante real interest rate yield on Moody's Baa-rated corporate bonds. Journal of Economics and Finance, 34(3), 301-307. http://dx.doi.org/10.1007/s12197-008-9074-y

Cebula, R. J., Angjellari-Dajci, F., \& Foley, M. (2014). An exploratory empirical inquiry into the impact of federal budget deficits on the ex post real interest rate yield on ten year Treasury notes over the last half century. Journal of Economics and Finance, 38(4), 712-720. http://dx.doi.org/10.1007/s12197-014-9280-8

Feldstein, M. (1976). Perceived wealth in bonds and social security: A comment. Journal of Political Economy, 84(2), 331-336. Retrieved from http://www.jstor.org/stable/1831904

Guo, H., \& Kliesen, K. L. (2005). Oil price volatility and U.S. macroeconomic activity. Federal Reserve Bank of St. Louis Review, 87(6), 669-683.

Gylfason, T., \& Risager, O. (1984). Does devaluation improve the current account? European Economic Review, 25(1), 37-64. http://dx.doi.org/10.1016/0014-2921(84)90070-9

Hamilton, J. D. (1996). This is what happened to the oil price-macroeconomy relationship. Journal of Monetary Economics, 38(2), 215-220. http://dx.doi.org/10.1016/S0304-3932(96)01282-2

Kalyoncu, H., Artan, S., Tezekici, S., \& Ozturk, I. (2008). Currency devaluation and output growth: an empirical evidence from OECD countries. International Research Journal of Finance and Economics, 14(3), 232-238. 
Kilian, L. (2008a) The economic effects of energy price shocks, Journal of Economic Literature, 46(4), 871-909. http://dx.doi.org/10.1257/jel.46.4.871

Kilian, L. (2008b). Not all oil price shocks are alike: disentangling demand and supply shocks in the crude oil market. CEPR Discussion Paper, 5994. Retrieved from http://citeseerx.ist.psu.edu/viewdoc/download?doi=10.1.1.168.3003\&rep=rep1\&type=pdf

Kim, G., An, L., \& Kim, Y. (2015). Exchange rate, capital flow and output: developed versus developing economies. Atlantic Economic Journal, 43(2), 195-207. http://dx.doi.org/10.1007/s11293-015-9458-2

Kompetenzzentrum Forschungsschwerpunkt Internationale Wirtschaft. (2016). Entwicklung des oesterreichischen Warenaussenhandels. Retrieved from http://www.fiw.ac.at/index.php?id=612

Moreira, A. R. G. F. (2009). The macroeconomic effects of (different) oil shocks: a VAR approach. Retrieved from http://run.unl.pt/bitstream/10362/9455/1/Moreira_2009.pdf

Segal, P. (2011). Oil price shocks and the macroeconomy. Oxford Review of Economic Policy, 27(1), 169-185. http://dx.doi.org/10.1093/oxrep/grr001

The Oesterreichische Nationalbank. (2016). Retrieved from https://www.oenb.at/

World Energy Council. (2015). 2015 Energy trilemma index. Benchmarking the sustainability of national energy systems. Retrieved from http://www.worldenergy.org/data/trilemma-index/country/austria/

\section{Copyrights}

Copyright for this article is retained by the author(s), with first publication rights granted to the journal.

This is an open-access article distributed under the terms and conditions of the Creative Commons Attribution license (http://creativecommons.org/licenses/by/3.0/). 